\title{
Correction to: Eclipsing the Eclipse?: A Neo-Darwinian Historiography Revisited
}

\section{Max Meulendijks ${ }^{1}$ (D)}

Accepted: 12 August 2021 / Published online: 4 October 2021

(c) Springer Nature B.V. 2021

\section{Correction to: Journal of the History of Biology https://doi.org/10.1007/s10739-021-09650-9}

The original publication has been corrected. In the section Neo-Darwinism: Defending the "Purity" of Darwinism, a mistake was introduced after proofing. Please find here the correct sentence:

Ernst Mayr noted that neo-Darwinism "was coined by [George] Romanes in 1895 as a designation of Weismann's theory” (Mayr 1984, p. 146). Reif, Junker and Hossfeld took Romanes's 1895 claim as the basis as well, but noted that it designated an exclusive emphasis on natural selection by Weismann and Wallace (Reif et al. 2000, p. 43).

Publisher's Note Springer Nature remains neutral with regard to jurisdictional claims in published maps and institutional affiliations.

The original article can be found online at https://doi.org/10.1007/s10739-021-09650-9.

Max Meulendijks

Mmeulendijks01@qub.ac.uk

1 Belfast, UK 